\title{
"They declared war and made their decision to prefer might to right": Thucydides on the use of force among states
}

Marcelo de Araújo

\author{
Marcelo de Araújo \\ Professor da Universidade Federal do Rio de Janeiro. \\ E-mail: marcelo.araujo@uerj.br \\ ORCID: https://orcid.org/0000-0001-8934-6195
}

\section{Introduction}

When we think of the contributions made by the ancient Greek, the philosophy of Socrates and Plato, the plays by Sophocles, Euripides, and Aristophanes, or the historical thinking of Herodotus and Thucydides may come to or minds. Between the fifth and fourth centuries BCE, Athens set the stage for unprecedented cultural developments in the history of humankind. However, we sometimes forget that the historical period in which these authors lived and produced their masterpieces was also a time of war and plague. Some way or other, all these authors participated in the Peloponnesian War. And the Athenians, who were a major power at the beginning of the conflict, emerged as the defeated party in the end.

The main source of information we have about the Peloponnesian War is Thucydides' work known as the Peloponnesian War. Thucydides took an active part in the war as a general on the Athenian side. But after failing to protect a city, of strategic value for the Athenians, he lost his position as a general and was forced into exile. It is in the exile, then, that Thucydides writes the Peloponnesian War, seeking to take into consideration the accounts provided by all parties involved in the conflict. ${ }^{i}$ The text, though, remained unfinished. And it is unclear whether the order of chapters, as displayed in most modern editions, matches Thucydides' original plan. It is not my intention here to examine the structure of the Peloponnesian War as a whole. My goal is far more modest: I intend to focus only on a few specific passages in which Thucydides discusses the causes of war and the reasons for violent conflict among human beings.

\section{Violent conflicts and human nature}

In times of war, and more specifically in the period following the devastation caused by major military conflicts, we feel perhaps more inclined - more than in times of peace - to ask why human beings resort to violence as a means for the resolution of conflicts. In the period following the Peloponnesian War, the question concerning the causes of war was discussed both in plays and philosophical texts. Thucydides' text can be understood as a further contribution to this debate. It might be expected, though, that in the Peloponnesian War Thucydides was mainly concerned with providing an account of the violence exerted by states or city-states against each other. However, in 
Marcelo Araújo

the Peloponnesian War, Thucydides deals not only with the reasons for the violence among city-states, but also with the reasons for violence within the city-states.

In the antiquity, most cities had the autonomy to create their own laws, or to trade with one another, to declare wars, or to enter into peace agreements. Cities functioned, for all intents and purposes, as states, and this is why we now usually refer to them as city-states. According to Thucydides, during the Peloponnesian War, conflicts among citizens within the city-states were sometimes more violent than conflicts among the city-states. Consider, for instance, these passages from Book III:

[4] During seven days that Eurymedon stayed with his sixty ships, the Corcyraeans were engaged in butchering those of their fellow-citizens whom they regarded as their enemies: and although the crime imputed was that of attempting to put down the democracy, some were slain also for private hatred, others by their debtors because of the monies owed to them. [5] Death thus raged in every shape; and, as usually happens at such times, there was no length to which violence did not go; sons were killed by their fathers, and suppliants dragged from the altar or slain upon it; while some were even walled up in the temple of Dionysus and died there. ii [...]

"In peace and prosperity states and individuals have better sentiments, because they do not find themselves suddenly confronted with imperious necessities; but war takes away the easy supply of daily wants, and so proves a rough master, that brings most men's characters to a level with their fortunes.iii $[\ldots]$

[2] In the confusion into which life was now thrown in the

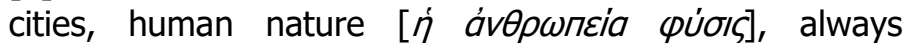
rebelling against the law and now its master, gladly showed itself ungoverned in passion, above respect for justice, and the enemy of all superiority. ${ }^{\text {iv }}$

The political instability resulting from the war among city-states undermined the mutual trust that previously existed within each city-state. Minor grievances, which would not have had major consequences in times of peace, ended up in mutual hostilities, aggressions, and death. But why did this happen? After all, a city's chance of winning the war would also depend on its capacity to promote internal cohesion and mutual cooperation. According to Thucydides, "human nature" itself was the main driving force behind the violence. Thucydides suggests, for instance, as we can read in the last passage quoted above, that human nature prompts human beings to aggression even when there are laws that restrain mutual violence. In periods of anarchy and social upheaval, when laws lose their efficacy, which is necessary to stop individuals from harming each other, human beings' natural propensity for violence becomes even more apparent.

If human nature is really prone to mutual aggression, as Thucydides suggests, then the only way to preclude the widespread violence that would result from total anarchy is to create (or re-create, as the case may be) and maintain the conditions 
Marcelo Araújo

under which individuals feel motivated to obey the laws. But the conditions under which individuals feel motivated to obey the law vary greatly depending on two different kinds of human interaction: [1] the interaction among individuals within the cities-states (or states) and [2] the interaction among cities-states (or states). In this lecture, I will focus mainly on theories that address the first kind of interaction, namely theories that deal with what goes on inside of the states.

The Greek word for "city" is polis. This is the word from which the word "political" is derived. Although the word "politics" is used as a noun, it originally had the form of an adjective, which was used to refer to the relations and circumstances that characterized human life within the polis. The individual cities in the ancient world could cooperate with each other, but they did not form super-polis. The situation is not different nowadays: states can cooperate with each other, but they do not form an allencompassing world state with laws and courts that have, at international level, the same force, efficacy and legitimacy that domestic laws and courts usually have within each state. It is no wonder, then, that the great classical work of political and legal philosophy have given more attention to the question as to how to prevent anarchy within a political community (the state or the city-state) than to the question as to how to prevent anarchy in the international domain. Anarchy, within a political community, is an anomaly. In the international domain, however, anarchy prevails, for the international domain, literally speaking, does not form a political community - it is not like a polis as seen through a magnifying glass.

In the domestic sphere, we can create mechanisms that have the force and the legitimacy to maintain the domestic order. In the international arena, however, there is no such mechanism. No state (or state representative) can be legitimately arrested by a world police force, or tried and convicted by a supranational court, as easily as individuals are arrested, tried, and convicted on a daily basis at a domestic level. In the international arena, order is guaranteed mostly, though not exclusively, by the balance of power, rather than out of a sense of respect for international laws or international courts. Within the states we can create laws in order to prevent an individual from accumulating too much power, to the point of posing a threat to the lives of other individuals. We can, for example, adopt laws that prohibit individuals from carrying firearms in a public place without proper authorization. When the law is violated, we can rely on the police, or some similar authority, to punish violators and to re-establish the order. But whom can we rely upon when a state acquires, or attempts to acquire, nuclear weapons, which represent a real threat to the security of other states? There is no world police force that has the power and the legitimacy to prevent this from happening in the international domain analogous to the national police forces, which prevent unauthorized individuals from carrying firearms in public places. In the international arena, order is usually maintained through the balance of power and diplomacy.

This understanding of the nature of the relationship among states is often called "realism in international relations", "political realism", or sometimes also realpolitik. The doctrine of political realism in international relations has been often criticized. There are, indeed, authors who describe the nature of international relations in less dramatic terms. For them, there is more cooperation and order within the international sphere than the realists seem willing to admit. However, the systematic rejection of political realism is more recent than one might perhaps suppose. Many classical works of political philosophy and legal thought, directly or indirectly, endorse a 
Marcelo Araújo

version of realism. And Thucydides, for reasons we shall see below, is often considered the founder of political realism.

\section{The debates of Mytilene and Melos}

Thucydides was certainly not the first historian in antiquity. Before him, Herodotus, for instance, had already provided an extensive account of the war the Greeks had fought against the Persians in a work known as Histories. But Thucydides, unlike Herodotus, did not include metaphysical or religious explanations in his account of the war. ${ }^{\vee}$ Thucydides reconstructs the Peloponnesian War as the result of a disruption in the balance of power that had prevailed before the war.

[2] Never had so many cities been taken and laid desolate, here by the barbarians, here by the parties contending (the old inhabitants being sometimes removed to make room for others; never was there so much banishing and blood-shedding, now on the field of battle, now in the strife of action. [...] [6] The real cause I consider to be the one which was formally most kept out of sight. The growth of the power of Athens, and the alarm which this inspired in Lacedaemon, made war inevitable. ${ }^{\mathrm{vi}}$

In this passage, Thucydides does not describe the enemies of the Athenians as morally corrupted people. For Thucydides, from the point of view of each party involved in the war, the question as to which side was just or unjust, moral or immoral, was not as important as the question as to how to preserve and to promote one's own internal security. The Lacedaemonians (or Spartans) resorted to war against the Athenians for the same sort of reason the Athenians themselves would have resorted to war in the same circumstances. And the reason for this was the increasing power of one of the actors in the region. Both the Lacedaemonians and the Athenians were interested in maintaining their own security, for each party could only rely on itself to promote their internal security. In order to understand how the disruption in the balance of power was perceived as a threat to the internal security of each city-state involved in the conflict, I would like to focus on two well-known passages from the Peloponnesian War, namely the "Mytilene debate" and the "Melos dialogue". The first passage is from Book III (chapters 35-50) and the second passage stems from Book V (chapters 84-114). In these passages, Thucydides draws attention to a problem that remains relevant today: do we still have compelling reasons to act in accordance with principles of justice when what we perceive as just is also disadvantageous, or sometimes even dangerous to our own security? The position defended by the Athenians in the passages from the Peloponnesian War that I would like to examine here is that, when we are not in a position to reconcile justice with self-interest, security should always take precedence over justice.

I leave open the question as to whether Thucydides' description of the Athenian attitude towards the other cities is the kind of attitude he himself would recommend. It is not implausible to suppose that Thucydides drew attention to the realist attitude, advanced by the Athenians, in order to show that political realism should be rejected. After all, the Athenians ended up defeated in the war, even though - or perhaps 
Marcelo Araújo

precisely because - they considered their own security more important than being just towards the other city-states. Thucydides is undoubtedly an important name in the tradition of political realism, but perhaps because of his criticism rather than his endorsement of a realist attitude.

In the debate in Mytilene, Thucydides initially describes the punishment the Athenians wanted to impose on the inhabitants of the island of Mytilene for not supporting the Athenian side during the war. The punishment consisted in killing the entire male population of the island. Women and children should only be enslaved. Soldiers from the Athenian side were, then, sent to Mytilene in a trireme in order to carry out the decision. The next day, however, as the soldiers rowed on to Mytilene, the Athenians wondered whether they should not reconsider their decision. Was not the punishment they were about to inflict on the inhabitants of Mytilene too harsh and cruel? The Athenians could not agree over which view to adopt: some argued that the decision to punish Mytilene should be kept, while others proposed to reconsider the decision. Cleon argued in favor of maintaining the initial decision: to kill the entire male population and enslave the others. Diodotus, on the other hand, held that a new trireme should be sent to Mytilene in order to communicate that the previous command was cancelled.

Cleon argues that it was right to retaliate the aggression the Mytilenians had inflicted on the Athenians. According to Cleon, the Mytilenians themselves "declared war and made their decision to prefer might to right". vii For this reason, Cleon argues that the initial decision should be maintained: "Let them now therefore be punished as their crime requires." "viii Moreover, sticking to the initial decision would be not only just, but also advantageous. Firstly, because the punishment would discourage other cities from rebelling against Athens. If the Athenians were mild towards the Mytilenians and withdrew their initial decision, other cities might feel encouraged to rebel and not to take the Athenian threats seriously. And secondly, it would be naive to assume that, if the Athenians would change their minds, the Mytilenians would be grateful. On the contrary, now that the Athenians had decided to inflict such a cruel punishment, the Mytilenians could already be considered their enemies. ${ }^{i x}$ Cleon also argues that clinging to the original decision would be both fair and prudent:

To sum up shortly, I say that if you follow my advice you will do what is just towards the Mitylenians, and at the same time expedient; while by a different decision you will not oblige them so much as pass sentence upon yourselves.

For Cleon, therefore, in this case, there is not a conflict between justice and self-interest. Justice, in this particular situation, would, indeed, promote the interest of the Athenians. Let us now turn to the reasons given by Diodotus for the reconsideration of the original decision. Diodotus does not deny that the inhabitants of Mytilene should be punished. But he is more concerned with what, in this particular case, would be more advantageous for Athens. Unlike Cleon, Diodotus argues that it would be more advantageous for Athens to spare the Mytilenians, but with one condition: the Athenians should levy heavy taxes on the Mytilenians. The taxes would contribute to the Athenian war effort. Diodotus' conclusion toward the end of his speech is the following: 
However, I have not come forward either to oppose or to accuse in the matter of Mitylene; indeed, the question before us as sensible men is not their guilt, but our interests. [2] Though I prove them ever so guilty, I shall not, therefore, advise their death, unless it be expedient; nor though they should have claims to indulgence, shall I recommend it, unless it be clearly for the good of the country. [3] I consider that we are deliberating for the future more than for the present. ${ }^{x}$

[5] In short, I consider it far more useful for the preservation of our empire voluntarily to put up with injustice, than to put to death, however justly, those whom it is our interest to keep alive. As for Cleon's idea that in punishment the claims of justice and expediency can both be satisfied, facts do not confirm the possibility of such a combination. ${ }^{\mathrm{x}}$

Diodotus' point is that the punishment was, indeed, fair. However, it would not promote the Athenian interest during the war. Thus, when it is impossible to reconcile the demands of justice with the demands of self-interest, it would be better, according to Diodotus, to favour the most advantageous course of action for Athens. In the end, Diodotus' position prevailed and the punishment originally proposed against the population of Mytilene was withdrawn.

The discussion about the relationship between justice and self-interest in times of war appears in another passage from the Peloponnesian War, namely, in the dialogue between the Athenians and the inhabitants of the island of Melos. This part of the work is sometimes also referred to as the "Melian dialogue". It is the only part of Thucydides' text that has the explicit form of a dialogue. Unlike what happened in the debate in Mytilene, the "dialogue" in Melos does not have (so to speak) a happy end. This time, the punishment imposed on rebels is actually carried out. This is one of the most brutal episodes during the Peloponnesian War. The massacre imposed on the inhabitants of Melos is the subject matter of a tragedy written by Euripides called Troades, also known as The Trojan Women. The massacre is also mentioned in the comedy The Birds by Aristophanes. ${ }^{\text {xii }}$

Right at the beginning of the dialogue, the Melians argue that the Athenians are unjust, for the Athenians implicitly claim to have the right to judge and condemn those

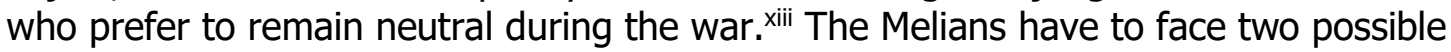
situations: [1] to cooperate or [2] not to cooperate with the Athenians. Cooperating with the Athenians, under the circumstances in which the Melians find themselves, means letting themselves to be enslaved by the Athenians. The Athenians argue that this option is the most advantageous for both parties: the Melians are not killed, and the Athenians are spared the work of having to kill every male adult in the island. ${ }^{\text {xiv }}$ Not cooperating with the Athenians, on the other hand, means going to war against the Athenians. This option has two main possible implications: [2.1] the Melians win the war, or [2.2] the Melians lose the war. The Melians know that they are weaker and that they have little chance of victory against the Athenians. Still, they choose to confront the Athenians, even considering that their defeat will most certainly entail the destruction of Melos. Why, then, do they prefer to go to war against the more powerful Athenians? The Melians present four reasons for their decision: [i] Wars are generally quite unpredictable so that luck can be on their side after all. ${ }^{\mathrm{xv}}[i i]$ The war against the 
Marcelo Araújo

Athenians is a just war. ${ }^{\text {xvi }}$ [iii] And because it is a just war, the gods will surely intervene so that justice will ultimately prevail. xvii Moreover, $[i v]$ the Melians are also confident that, as a matter of honor and ethnic affinity, the Lacedaemonians will be their allies in the confrontation against the Athenians. xviii None of these reasons, however, convinced the Athenians that they should retreat and leave the Melians alone.

The Athenians argue that questions about justice and injustice are only relevant when there is a balance of power between the parties involved. The very metaphor of the "balance of power" is used by the Athenians when they say, for example, that the Melians are weak and that they "hang on a single turn of the scale."xix Because they are in a disadvantageous position, the Melians, according to the Athenians, should put aside the discussion over justice and, instead, negotiate their own survival on terms established by the Athenians:

[...] you know as well as we do that right, as the world goes, is only in question between equals in power, while the strong do what they can and the weak suffer what they must. $x$

[...] Then you do not adopt the view that expediency goes with security, while justice and honor cannot be followed without danger; and danger the Lacedaemonians generally court as little as possible. ${ }^{x x i}$

The Athenians claim that if the Melians were the strongest party in the conflict, the Melians would behave towards the Athenians just like the Athenians behave towards the Melians. The Athenians also affirm that their own behavior falls in line with a sort of "natural law", a law that was not created by the Athenians themselves, and which will always exist wherever power is unequally distributed:

[2] Of the gods we believe, and of men we know, that by

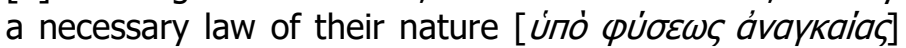
they rule wherever they can. And it is not as if we were

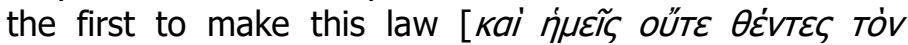
vómov], or to act upon it when made: we found it existing before us, and shall leave it to exist for ever after us; all we do is to make use of it, knowing that you and everybody else, having the same power as we have, would do the same as we do. ${ }^{x \text { xii }}$

There are, indeed, some philosophical theories that involve the idea of natural laws and natural rights. The assumption that there are natural laws and natural rights seems at first glance quite attractive and intuitive also in our everyday lives. The law that prohibits me from exceeding the speed limit is, for sure, a social convention. This rule varies from country to country, and even within the same country this law can vary over time, as cars become faster and safer. But the law that forbids me from killing other individuals, or that prohibits me from endangering the lives of people around me, does not seem to result from a social convention and does not seem to change so frequently in space and time as the laws that rule the speed limit on public roads. For this reason, one might go as far as to suggest that these laws are universal moral principles, or that these are "natural laws" that command us to perform certain actions quite irrespectively of any social conventions. 
Marcelo Araújo

It is not my intention to examine here the problems that philosophical theories on natural laws and natural rights involve. It may well be the case that some basic moral rules have been recognized as binding in every human society throughout the centuries, but it does not follow from this that these rules are in any sense "natural", i.e. that they are inherent to human nature, or human reason. My intention for now is simply to emphasize that the main idea behind natural law and natural rights theories are, at first glance, quite attractive and intuitive. And because this idea is so attractive and intuitive, it is also quite old. From antiquity down to modern times many philosophers have argued for the existence of natural law and natural rights theories. However, when this idea occurs in the speech of the Athenians, in the passage quoted above, it has a very unusual meaning. For it is not used to refer to universal moral principles or to a conception of natural justice. It is used, rather, to refer to the assumption that, as far as human relations are concerned, the claims of the strongest party always prevail over those of the weaker parties.

This less frequent understanding of the idea of a natural law was also endorsed by the sophists in antiquity, and resumed by Thomas Hobbes in the seventeenth century. It is not clear, however, whether Thucydides himself understands the idea of natural law in this way, or whether he only describes how the Athenians justified their own assumption according to which in times of war the stronger should command and the weaker should obey. Thucydides may perhaps have chosen the form of a dialogue in order to stress his distancing from the position defended by the Athenians in their conflict with the Melians. The fact that the Athenians had lost the war may even be a sign that Thucydides himself did not agree with the realist attitude of the Athenians. If this is true, then Thucydides was not himself a realist, but the first author in the tradition of political thought to criticize the doctrine of political realism.

\section{Conclusion}

The conditions for the enforcement of laws among states are quite different from the conditions that prevail within the states (or city-states). And it is for this reason that, as I have suggested earlier, most texts in the tradition of political and legal philosophy gave more attention to issues related to what goes on within the states. It does not mean, of course, that questions about international politics or international justice are entirely absent in the texts by Plato, Aristotle, Thomas Aquinas, Machiavelli, Thomas Hobbes, John Locke, Jean-Jacques Rousseau, Immanuel Kant, Jeremy Bentham, John Stuart Mill, Karl Marx, John Rawls, and other important authors in the tradition of philosophical and legal thought. It is always possible to find among these authors passages, or even whole treatises - such as the Perpetual Peace (1795) by Kant, or The Law of Peoples (1999) by Rawls - that deal with philosophical issues that arise in our theorizing on the structure of international relations. But these authors were generally more concerned with the relations that take place, or should take place, within the states than with the relation among states.

It is clear, though, that in the course of the $21^{\text {st }}$ century, ethics and political philosophy cannot neglect normative issues that result from the interaction - or lack of interaction, as the case may be - among states. It is the first time in the history of human civilization that human beings may have to face the prospect of witnessing their own demise as a species. Questions relative to nuclear wars, dangerous climate change, and pandemics - to mention just a few global risks - require global solutions 
Marcelo Araújo

and strong international cooperation. Thucydides may well have been the first author to call attention to what would prove to be the enduring force of political realism. But he may very well have been, too, the first author to have witnessed the shortcomings of realism as a kind of approach to international relations. xxiii

(Recebido para publicação em setembro de 2020)

(Reapresentado em setembro de 2020)

(Aprovado para publicação em outubro de 2020)

\section{Cite este artigo}

ARAÚjO, Marcelo, 2020. "They declared war and made their decision to prefer might to right": Thucydides on the use of force among states. Revista Estudos Políticos: a publicação semestral do Laboratório de Estudos Hum(e)anos (UFF). Rio de Janeiro, Vol.11 | N.1, pp. 83-93, outubro de 2020.

\section{Notas}

1. huc. 5.26 (Thucydides, The Peloponnesian War. Book 5, chapter 26. London, J. M. Dent; New York, E. P. Dutton, 1910): "I lived through the whole of it, being of an age to comprehend events, and giving my attention to them in order to know the exact truth about them. It was also my fate to be an exile from my country for twenty years after my command at Amphipolis; and being present with both parties, and more especially with the Peloponnesians by reason of my exile, I had leisure to observe affairs somewhat particularly. [6] I will accordingly now relate the differences that arose after the ten years' war, the breach of the treaty, and the hostilities that followed." English and Greek texts available at Perseus Digital Library Project: http://www.perseus.tufts.edu/hopper/text?doc=Perse us:text:1999.01.0200.

2. Thuc. 3.81 .

3. Thuc. 3.82 .

4. Thuc. 3.84 .

5. Thuc. 1.22: "[4] The absence of romance in my history will, I fear, detract somewhat from its 
Marcelo Araújo

interest; but if it be judged useful by those inquirers who desire an exact knowledge of the past as an aid to the interpretation of the future, which in the course of human things must resemble if it does not reflect it, I shall be content. In fine, I have written my work, not as an essay which is to win the applause of the moment, but as a possession for all time."

6. Thuc. 1.23.

7. Thuc. 3.39 .

8. Thuc. 3.39.

9. Thuc. 3.40 .

10. Thuc. 3.44 .

11. Thuc. 3.47.

12. See for instance A. Maria van Erp Taalman Kip. "Euripides and Melos." Mnemosyne, vol. 40, no. 3/4, 1987, pp. 414-419. Available at: www.jstor.org/stable/4431648. Aristophanes refers to the Melos massacre at line 186. Available at: http://www.perseus.tufts.edu/hopper/ (Greek text and English translation).

13. Thuc. 5.86: "Melian commissioners: [...] as we see you are come to be judges in your own cause, and that all we can reasonably expect from this negotiation is war, if we prove to have right on our side and refuse to submit, and in the contrary case, slavery."'

14. Thuc. 5.93

15. Thuc. 5.102.

16. Thuc. 5.86 .

17. Thuc. 5.104 .

18. Thuc. 5.104.

19. Thuc. 5.103.

20. Thuc. 5.89.

21. Thuc. 5.107.

22. Thuc. 5.105.

23. I am grateful to Peter Stemmer (University of Konstanz) and to Fernando Rodrigues 
"THEY DECLARED WAR AND MADE

Marcelo Araújo

(Federal University of Rio de Janeiro) for critical comments on an early draft of this text. 